\title{
EQUILIBRIUM
}

Quarterly Journal of Economics and Economic Policy

2016 VOLUME 11 ISSUE 2, June

p-ISSN 1689-765X, e-ISSN 2353-3293

www.economic-policy.pl

Mahdi Ghodsi, M. \& Michalek, J. J. (2016). Technical Barriers to Trade Notifications and Dispute Settlement within the WTO. Equilibrium. Quarterly Journal of Economics and Economic Policy, 11(2), 219-249. DOI: http://dx.doi.org/10.12775/ EQUIL.2016.010

Mahdi Ghodsi* The Vienna Institute for International Economic Studies, Austria

Jan Jakub Michalek ${ }^{* *}$

University of Warsaw, Poland

\section{Technical Barriers to Trade Notifications and Dispute Settlement within the WTO}

JEL Classification: $F 13 ; F 53$

Keywords: trade policy; technical barriers to trade (TBTs); WTO, dispute settlement

\begin{abstract}
The aim of this paper is to verify empirically whether the Specific Trade Concerns (STCs) regarding Technical Barriers to Trade (TBTs) notifications by WTO members can serve as an early warning system for past and future disputes (DS) covering allegedly trade restricting TBTs. WTO members, in order to increase transparency of trade policies, have made efforts to compile data on notified TBTs. For several years the WTO provides a TBT dataset, used in our paper, which covers the STCs raised by its members ("reverse" notifications). From 1995-2011, there have been 45 requests for consultation under the Dispute Settlement (DS) Body of the World Trade Organization (WTO) in order to identify possible violations of the technical barriers to trade (TBT) agreement. This paper attempts to find the linkages between DS cases citing the TBT agreement and the STC data regarding TBTs. The DS Body's decisions regarding possible violations
\end{abstract}

(C) Copyright Institute of Economic Research

Date of submission: February 1, 2016; date of acceptance: May 6, 2016

* Contact: ghodsi@wiiw.ac.at, The Vienna Institute for International Economic Studies (wiiw), Rahlgasse 3, 1060 Wien, Austria

*** Contact: michalek@wne.uw.edu.pl, University of Warsaw, Faculty of Economic Sciences, Długa 44/50, 00-241 Warsaw, Poland 
of the TBT agreement are discussed in detail. Afterwards, we analyze, descriptively and econometrically, the relationship between notified STCs and DS consultations regarding TBTs.

\section{Introduction}

Eight Multilateral Rounds of Trade negotiations under the GATT have contributed significantly to the reduction of import tariffs among World Trade Organization (WTO) members. However, non-tariff measures (NTMs) have become relatively more important. For example, the MultiAgency Support Team (MAST) ${ }^{1}$ described NTMs as follows: "Non-tariff measures are generally defined as policy measures other than ordinary customs tariffs that can potentially have an economic effect on international trade in goods, changing quantities traded, or prices or both."

According to the MAST classification (UNCTAD/DITC/TAB/2012/2), NTMs include 16 categories. The first and the second category, which are the most frequently notified by WTO members, are sanitary and phytosanitary (SPS) measures, and technical barriers to trade (TBT). TBTs are "measures referring to technical regulations, and procedures for assessment of conformity with technical regulations and standards, excluding measures covered by the SPS Agreement."

The general aim of the TBT agreement, concluded during the Uruguay Round, is to ensure that technical regulations and standards, as well as testing and certification procedures, do not create "unnecessary obstacles" to international trade. However, it is recognized that countries have the right to establish protection, at the levels they consider appropriate, for example, for human, animal or plant life or for health or environmental protection. Countries should not be prevented from taking the necessary measures to ensure that those levels of protection are met. Therefore, the Agreement encourages countries to use international standards where these are appro-

\footnotetext{
${ }^{1}$ The MAST group, as of July 2008, comprises of the following institutional members: the Food and Agriculture Organization of the United Nations (FAO), the International Monetary Fund (IMF), the International Trade Centre UNCTAD/WTO (ITC), the Organization for Economic Cooperation and Development (OECD/TAD), the United Nations Conference on Trade and Development (UNCTAD), the United Nations Industrial Development Organization (UNIDO), the World Bank (WB), and the World Trade Organization (WTO). Observers: the European Commission (EC), the United States International Trade Commission (USITC), and the United States Department of Agriculture (USDA). UNCTAD and the World Bank jointly coordinate the MAST group. The MAST group reports to the Group of Eminent Persons, which is convened by the director general of UNCTAD.
} 
priate, but it does not require them to change their levels of protection as a result of standardization.

Busch and Reinhardt (2003) analyse Dispute Settlement (DS) under GATT and the WTO from 1980 to 2000. Using econometrics analysis, they find outcomes of DS cases that are more in favour of developed countries since 1995. As of 31 December 2012, there have been 454 requests for consultations filed under the DS Understanding. Since 1995 to 2012, the TBT agreement has been cited in 45 WTO cases. This is about one tenth of all disputes, showing the real significance of TBTs. It is worth mentioning that in the majority of DS cases multiple agreements are cited. However, according to the WTO report (2012), out of the 393 disputes relating to the trade of goods from 1995-2011, TBTs have been cited in 10.2\% of them, which is the fifth agreement in terms of the number of citations. According to the complainants, the imposed TBT measures have been creating unnecessary obstacles to trade.

Technical barriers to trade, methodological issues related to product standards, and their policy implications have been studied widely in the literature (see: Otsuki et al., 1999). In some cases, the authors demonstrate the drastic disruption of trade flows resulting from the imposition of "legitimate" higher standards. For example, an analysis by Otsuki et al. (2001) on the impact of EU safety aflatoxin standards on the importing of food products from Africa shows that this new regulation decreases the health risk by 1.4 deaths per billion a year, while it reduces the imports from African countries by $64 \%$, i.e. about 670 million US dollars ${ }^{2}$. The analysis also suggests that the costs imposed on developing countries were much higher than the benefits in the EU after imposition of this regulation.

In another empirical analysis, Aisbett and Pearson (2012) have shown that countries imposing SPS regulations are usually acting in good faith. Moreover, a smaller tariff-binding overhang causes a higher probability of the imposition of new SPS measures. Based on the same econometric results, high environmental standards, healthcare, and institutional governance qualities are the main factors affecting the imposition of SPS. While other countries facing NTMs perceive them as a protectionism measure, the imposing country is actually imposing them in good faith to protect human health, safety, and other environmental qualities.

According to Kono (2006) many developed countries try to implement opaque and complex NTMs, instead of simple tariffs, in order to hide their

\footnotetext{
${ }^{2}$ Moreover, aflatoxin rarely causes death in developed countries while there is lack of conclusive scientific evidence for the relationship between aflatoxicosis and the amount of aflatoxin intake.
} 
policies from the public. The question of complementarity or substitutability between tariffs and NTMs has also been analysed in the literature. For instance, Ray (1981) found a causal relationship going from tariffs to NTMs in the US; meaning that NTMs are frequently supplements for tariffs. Substitutability of tariffs with antidumping measures has also been studied. From 1995 to 2004, after tariff reductions by WTO accessions, measures antidumping has been more frequently used by governments as a protectionist instrument. Another study by Moore and Zanardi (2011) suggests that the substitution of antidumping for tariff reductions happens only in the developing countries who have become heavy users of this measure. Substitutability of NTMs for tariffs has also been modelled in the theoretical framework by Yu (2000).

It has been demonstrated in many econometric studies that use of international standards in a given country usually increases exports from and imports into that country. On the other hand, the use of national standards in a given country usually increases its exports, but the implications for imports into that country are clear. In some cases, standards can facilitate imports, but in other cases, standards restrict such imports. In the case of sanitary and phytosanitary (SPS) measures, national standards are more likely to restrict imports; especially those from developing countries. The complex nature of TBTs frequently does not allow one to find the true motivation behind their implementation. Despite the declared, official motivation, sometimes it is difficult to prove whether or not they are in accordance with the TBT agreement (Swann, 2010).

Some authors (e.g. Swinnen \& Vandemoortele, 2012) exclusively categorized standards as barriers or catalysts to trade: barriers in the sense that some regulations might root from the special interest groups protecting domestic industries and causing trade prohibitions; and catalysts to trade pursuing the protection of consumers within a society, or reducing the information costs of the market, affecting trade positively. However, it is not yet evidently possible to distinguish between these two motives through the opaque nature of TBT and SPS.

Recent efforts by international organizations to provide databases on these measures have improved the transparency of NTMs. Reviewing inventories and trade instruments, Santana and Jackson (2012) found that GATT and WTO disputes are well reflecting the frequency of different NTMs applied by GATT/WTO members. The database on Specific Trade Concern (STC) raised on TBTs - compiled by the WTO secretariat - became one of the most important instruments in increasing trade policy transparency. These "reverse" notifications reflect the worries of other 
WTO members whether the officially notified measures will have negative impact on their exports.

In this paper, we analyze the STC database and try to find a likely relationship between the DSs held on TBTs and earlier STCs. In particular, we will verify whether TBT notifications can serve as an early warning system for past and future disputes involving the TBT agreement. The existence of this relationship and the analysis of STC database could help to indicate which TBTs can be a likely subject of future disputes.

The structure of this paper is as follows: in the next section, we will elaborate on the importance of transparency issues in WTO agreements. In the third section, a detailed description of TBT and STC data will be provided. The fourth section describes the relationship between the DSs and the TBT data. In the fifth section, we will provide an econometric analysis to find the linkages between raised TBT STCs and DS cases citing the TBT agreement. Finally, in the fifth section, the conclusions will be presented.

\section{Transparency in the Imposition of TBT}

The Preamble to the TBT agreement states: "no country should be prevented from taking measures necessary to ensure the quality of its exports, or for the protection of human, animal, and plant life or health, of the environment, or for the prevention of deceptive practices, at the levels it considers appropriate". However, "Members shall ensure that technical regulations are not prepared, adopted or applied with a view to, or with the effect of, creating unnecessary obstacles to trade." (Article 2.2$).^{3}$ Therefore, elasticity in introducing restrictive TBT measures is - in principle - limited. Technical standards are usually introduced to protect the interests of consumers (for health, safety or environmental reasons etc.), but they can also restrict the volume of international trade, as foreign suppliers might not be able to comply with the country's regulatory framework. Such restrictions on foreign competition may decrease welfare by allowing domestic firms to charge higher prices and by reducing the volume of trade (Ghodsi, 2015).

In principle, unnecessary obstacles to trade can emerge when (i) a regulation is more restrictive than necessary to achieve a given policy objective, or (ii) when it does not fulfil a legitimate objective. A regulation is more restrictive than necessary when the objective pursued can be achieved through alternative measures, which have less trade-restricting effects, tak-

\footnotetext{
${ }^{3}$ The results of the Uruguay Round (1994), the TBT agreement, page 139. All other citations of the TBT agreement come from the same source.
} 
ing into account the risks non-fulfilment of the objective would create. ${ }^{4}$ The obligation to avoid unnecessary obstacles to trade also applies to conformity assessment procedures (Article 5.1.2). An unnecessary obstacle to trade could result from stricter or more time-consuming procedures than are necessary to assess that a product complies with the domestic laws and regulations of the importing country.

There can be three main reasons for the imposition of regulatory measures. Firstly, TBT can serve as an instrument of public policy aiming at the protection of human health or safety, animal or plant life or health, or the environment. Secondly, from an economic point of view, TBT can be targeted at increasing of social welfare, in the case of market failures. For instance, mandatory labelling of products, a sub-category of TBT, will provide better information to consumers and other suppliers in the market, which can improve the efficiency of the market. Consequently, this will lead to a rise in social welfare, while it might incur some adaptation costs to supplier facing the regulation. Thirdly, a TBT measure can be caused by a political economy motivation, i.e., it can create an unnecessary obstacle to trade in order to protect special domestic interest groups. The first two reasons represent "good faith" of governments and are acceptable by the TBT agreement. The last approach restricts trade and violates the articles of TBT, SPS, and other agreements made by the WTO.

In developed countries, almost all tariff lines are bound within the schedules of concessions and thus duties cannot be increased. On the other hand, higher technical standards can be implemented in such a manner that they might protect the domestic industry against foreign ones. However, sometimes it is fairly difficult to find out whether or not a given TBT is in line with the TBT agreement. In other words, neither the aims of the TBT declared by the imposing governments, nor its trade effects, can provide a conclusive legal judgment. It is worth adding that, according to WTO regulations, governments should be transparent in implementing all trade policy instruments that they impose.

Asymmetric information is one of the major causes of market imperfections. Transparency decreases the asymmetry of information in the market. Thus, the efficiency of the international market can also be increased due to the symmetry of information (Geraats, 2002). TBT and SPS Agreements explicitly require a high level of transparency; the member states shall set up "enquiry points" providing information on technical regulations. WTO Members should also notify any new technical regulation, standard, and conformity assessment procedures to the WTO Secretariat. Finally, they

\footnotetext{
${ }^{4}$ Articles 2.3 and 2.4 of the TBT Agreement.
} 
should inform the Secretariat about any international agreements involving these issues. The number of relevant notifications is several hundred each year, and about $25 \%$ of them are submitted by the European Union.

The TBT agreement explicitly encourages Members to use existing "international standards or relevant parts of them" for their national regulations, unless "their use would be ineffective or inappropriate" to fulfil a given policy objective. Technical regulations, in accordance with relevant international standards, "shall be rebuttably presumed not to create an unnecessary obstacle to international trade" (Article 2.5). Similar provisions apply to conformity assessment procedures: international guides or recommendations issued by international standardizing bodies, are to be used in national procedures for conformity assessment unless they are "inappropriate for the Members concerned, inter alia, such reasons as national security requirements, ... protection of human health or safety, animal or plant life or health, or protection of the environment, ... fundamental technological or infrastructural problems",

Thus, the concept of transparency is well defined in the TBT agreement and is one of the key principles governing the WTO system". "WTO agreements also include multiple provisions aimed at improving the transparency of policy measures affecting trade. These provisions can be grouped into the following four categories: (a) publication requirements; (b) notification requirements; (c) the Trade Policy Review Mechanism and the monitoring reports; (d) the possibility of raising specific trade concerns (STC) in the SPS and TBT committees and in the dispute settlement mechanism (DSM)." 7 These provisions increase the transparency of TBTs maintained by member states. However, governments pursuing political economy goals, aimed at supporting interest groups, can be reluctant to notify new measures. In such cases, member states can raise specific trade concerns on the measures maintained by other countries. For example, exporters facing new obstacles to trade usually inform their government and ask for support within the framework of the WTO. Thus, even if a TBT measure is notified by a WTO member, other countries can raise concerns on

\footnotetext{
${ }^{5}$ Article 5.4.

${ }^{6}$ The concept of transparency can have many attributes when applied to policy measures. According to Geraats (2002), transparency should be completed by the following steps: 1 - ensuring the openness of policy; 2 - references to economic, scientific, and technical aspects; 3 - procedural and implementation transparencies; 4- publications and notifications of policy. In general, articles of GATT and TBT agreements oblige members to carry out all of these steps for the imposition of NTMs.

${ }^{7}$ World Trade Report 2012, page 96. DSM: Understanding on rules and procedures governing the settlement of disputes.
} 
those TBTs. In fact, STCs raised on TBTs are a subset of all TBTs maintained (either directly notified or not) by all WTO members. The WTO - in order to increase transparency - constructed a database on STCs of TBTs and SPSs. The STC features are presented in the next section.

\section{Technical Issues of the TBT Dataset of STC}

WTO members can discuss issues related to specific measures imposed by other members at the meetings of the TBT and SPS committees. The STCs are reverse notifications that inform the WTO secretariat about other members' concerns regarding notified measures. The WTO Secretariat has compiled the data for all of the concerns related to TBT and SPS from 1995 to $2011^{8}$. We focus our attention on the TBTs included in the TBT dataset of STCs. The data has been compiled from two sources: First, from WTO notifications, including all direct notifications by imposing countries. The second source is gathered from TBT Committee minutes, which comprise STCs raised by members facing TBTs imposed by others. When the information from both sources is not equivalent, the one from the TBT Committee minutes is preferred and included in the dataset.

The STC data contains 12,426 observations $^{9}$ for $317^{10}$ notifications over various types of products (tariff lines at a two to six-digit level of the Harmonized System). All 317 STCs are treated as the first (original) source, and only 251 of them are included in the WTO notifications (secondary source). In fact, for 66 cases, countries imposing TBT did not notify the WTO and their trade partners informed the WTO instead. The STC data covers the products about which the concern was raised, and not the products covered by new TBTs. Therefore, the TBTs imposed in accordance with the TBT agreement, not creating unnecessary obstacles to trade, are presumably not included in the STC database.

8 The data is available at: http://www.wto.org/english/res_e/publications_e/ wtr12_dataset_e.htm.

${ }^{9}$ Each observation refers to a row on the database, which represents the product in the focus of the STC raised by various countries (concerned ones) for a specific TBT imposed by another (maintaining) country. Each observation also covers different information such as the dates the STC was raised, notification numbers and symbols, the classification of the TBT, and some other descriptive issues from the minutes.

${ }^{10}$ The data shows 318 STCs, however, item 220 is missing from the data; thus, there exists only 317 STCs. Item number 220 also does not exist in the TBT Information Management System of the WTO. According to the description of the STC data, item 220 has been deleted because it was a duplication of item no. 219. 
Table 1 shows the top 10 countries (and/or groups of countries) maintaining TBT for which STCs were raised by other members most frequent$1 y^{11}$. Among 43 groups of countries with STC on TBTs, the leaders were the European Union (EU), including its 27 members, with 3138 observations covering 64 STCs, China with 1366 observations covering 39 STCs, and the United States with 1083 observations covering 35 STCs raised by others. According to the complete list, developing countries are at the bottom of the list. The World Trade Report 2012 formulates the same conclusions. Thus, developed countries are listed in the STC mechanism more frequently than developing countries in terms of maintaining or raising STCs. The econometric analysis in the Report shows that the trade coverage concerns are more frequents for developed countries rather than for developing ones. But, according to the WTO Report, the developing countries are becoming more active in both activities.

Table 1. 10 top countries (groups of countries) - respondents of STCs raised by other members

\begin{tabular}{llrrrrrr}
\hline No & $\begin{array}{c}\text { Member } \\
\text { Maintaining }\end{array}$ & $\begin{array}{c}\text { No. } \\
\text { Obs. }\end{array}$ & $\begin{array}{c}\text { No. } \\
\text { STCs }\end{array}$ & No & $\begin{array}{c}\text { Member } \\
\text { Maintaining }\end{array}$ & $\begin{array}{c}\text { No. } \\
\text { Obs. }\end{array}$ & $\begin{array}{c}\text { No. } \\
\text { STCs }\end{array}$ \\
\hline $\mathbf{1}$ & European Union & 3138 & 64 & $\mathbf{6}$ & Brazil & 635 & 18 \\
\hline $\mathbf{2}$ & China & 1366 & 39 & $\mathbf{7}$ & Japan & 198 & 11 \\
\hline $\mathbf{3}$ & United States & 1083 & 35 & $\mathbf{8}$ & Indonesia & 613 & 10 \\
\hline $\mathbf{4}$ & Korea & 698 & 25 & $\mathbf{9}$ & Mexico & 509 & 9 \\
\hline $\mathbf{5}$ & India & 642 & 18 & $\mathbf{1 0}$ & Canada & 177 & 9 \\
\hline
\end{tabular}

Source: own calculations from the STC database.

The undenatured ethyl alcohol of an alcoholic strength by volume of less than $80 \%$ vol.; spirits, liqueurs and other spirituous beverages" (HS Code 2208), with 126 observations, is the most frequent product in STC dataset. Since there are many products at a four-digit level, the aggregated products are studied below at a two-digit level.

Table 2 shows the 10 most frequent products at a two-digit level of HS2 on which STCs were raised ${ }^{12}$. The order of the numbering of the groups of

\footnotetext{
${ }^{11}$ List of all countries maintaining TBT STCs can be found in Table 8.

${ }^{12}$ List of all 2-digit products within the HS classification at the focus of TBT STCs can be found in Table
} 
products is according to the decreasing number of STCs, and then the number of observations in the data. Beverages, Spirits and Vinegar products with code 22, at a two-digit level, are the most frequent products under the focus of STCs, which have been mentioned in the dataset 543 times.

Table 2. 10 most frequent products at a 2-digit of HS 2 level in the focus of STCs

\begin{tabular}{|c|c|c|c|c|}
\hline $\begin{array}{c}\operatorname{Ran} \\
\mathbf{k}\end{array}$ & HS & Product description & $\begin{array}{l}\text { N. } \\
\text { STC }\end{array}$ & $\begin{array}{l}\text { N. } \\
\text { Obs. }\end{array}$ \\
\hline 1 & 22 & Beverages, spirits and vinegar & 57 & 543 \\
\hline 2 & 85 & $\begin{array}{l}\text { Electrical machinery and equipment and parts thereof; sound } \\
\text { recorders and reproducers, television image and sound }\end{array}$ & 41 & 428 \\
\hline 3 & 2 & Meat and edible meat offal & 40 & 480 \\
\hline 4 & 84 & $\begin{array}{l}\text { Nuclear reactors, boilers, machinery and mechanical appli- } \\
\text { ances; parts thereof }\end{array}$ & 40 & 291 \\
\hline 5 & 4 & $\begin{array}{l}\text { Dairy produce; birds' eggs; natural honey; edible products of } \\
\text { animal origin, }\end{array}$ & 38 & 388 \\
\hline 6 & 3 & $\begin{array}{l}\text { Fish and crustaceans, molluscs and other aquatic inverte- } \\
\text { brates. }\end{array}$ & 36 & 290 \\
\hline 7 & 21 & Miscellaneous edible preparations. & 34 & 224 \\
\hline 8 & 19 & $\begin{array}{l}\text { Preparations of cereals, flour, starch or milk; pastrycooks' } \\
\text { products. }\end{array}$ & 34 & 191 \\
\hline 9 & 16 & $\begin{array}{c}\text { Preparations of meat, of fish or of crustaceans, molluscs or } \\
\text { other aquatic invertebrates. }\end{array}$ & 34 & 188 \\
\hline 10 & 15 & $\begin{array}{c}\text { Animal or vegetable fats and oils and their cleavage prod- } \\
\text { ucts; prepared edible fats; waxes. }\end{array}$ & 33 & 770 \\
\hline
\end{tabular}

Source: own calculations from the STC database.

Apart from product 22, it can be observed that food, beverages, and agricultural products are the main issues with regards to TBTs, while they make up the majority of the top 10 most frequent products in the focus of TBT STCs. The second product in Table 1, with the HS Code 85, includes 'Electrical machinery and equipment and parts thereof; sound recorders and reproducers, television image and sound recorders. This shows that STCs are also raised for technical reasons and not only for health and safety issues. HS-Codes 02, 03, 04, 15, 16, 19, 21 and 22 are food related products as mentioned in the STC data description. HS-Code 84 includes all of the products related to nuclear reactors, boilers, machineries, and some mechanical appliances. Thus, there is a wide variety of products representing high or low technology that can raise concerns of other WTO members. 
Figure presents the trends of STCs (items) and the number of related observations (rows) for each year ${ }^{13}$. It shows the upward trends of STCs during the periods 1995-1998, 1999-2002, and 2005-2009, while there were sudden or gradual decreases outside of these periods. In general, there was an increasing trend of concerns raised by WTO members. Trends in the number of observations demonstrate a similar pattern to the STC trends, but in some years, this pattern did not coincide. There is no clear correlation between the number of STCs and the number of observations, because of frequent repetitions in some STCs. However, despite the data misspecification that is due to multiple inclusions, STCs with a large number of observations in the data usually cover a large number of products.

Figure 1. Trends of STCs and observations in the data raised by members

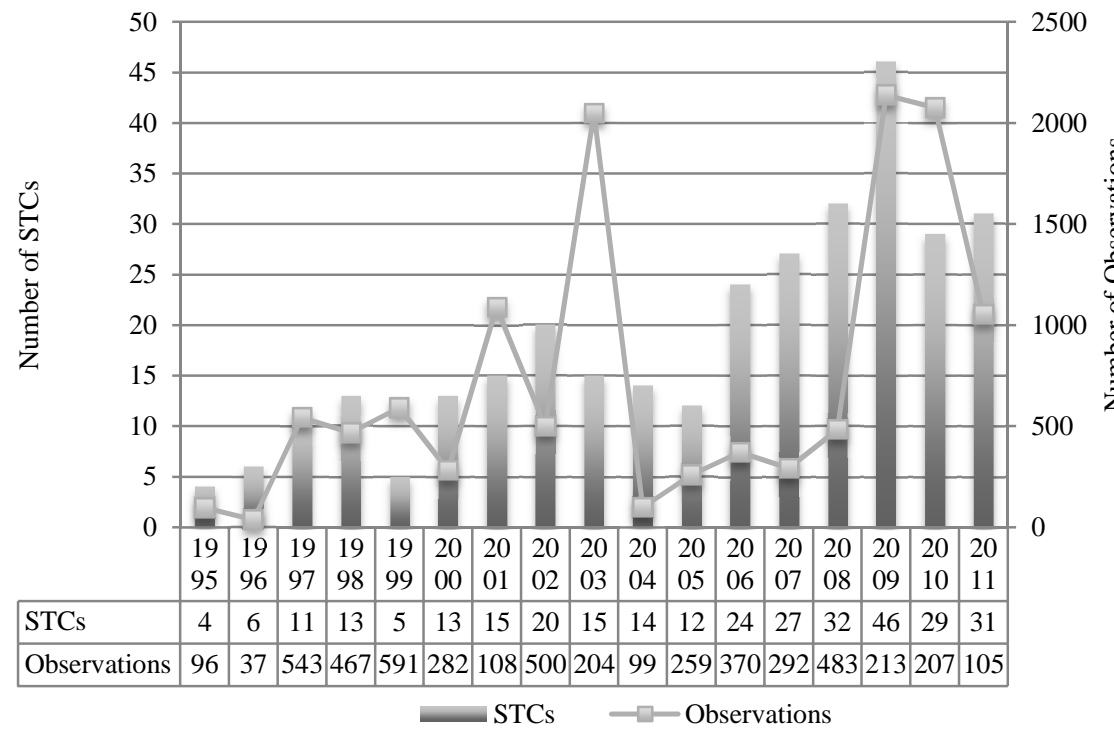

Source: STC database.

According to Figure, there was a sudden increase in the number of STCs and observations after 2008. The last financial crisis probably stimulated some governments to impose new NTMs for emergency reasons. These

${ }^{13}$ It is worth mentioning that in the SPS STC data provided by the WTO, the dates that the STC cases were resolved were also mentioned, while there is no such information in the TBT STC database. Therefore, some STCs on TBT might have been resolved during those years, but it was not mentioned in the data. 
TBTs with a large product coverage seem to be motivated by protectionist pressures. They can effectively restrict imports and are called emergency measures according to the World Trade Report in $2012^{14}$. In fact, during the recent financial crisis, some governments were probably encouraged to impose NTMs such as TBTs to help their domestic enterprises.

\section{Descriptive Analysis on the Linkages between Dispute Settlements and STCs}

A dispute at the WTO starts when a government of a member state believes that another member is violating one of the WTO agreements. The complaining member must identify the violated agreements and request consultation within the Dispute Settlement Mechanism (DSM). If consultations do not solve the problem, a WTO Member can request that a panel be set up. During 1995-2011, 45 cases have cited the TBT agreement in their request for consultation ${ }^{15}$. In this section, we will analyze these disputes and the linkages between them and the TBTs included in the STC.

Table 3 shows the summary of disputes in which the TBT agreement was cited. There is a geographical concentration of disputes. Since 1995, only seven groups of countries have been the respondent of forty-five cases of DS, citing violation of the TBT agreement. The European Union (and its 27 members of the WTO), were the most frequent respondent to DSs; 20 times in total. EU is maintaining 64 TBTs on which STCs are raised, which was the highest record among all members. While China is the second largest country in terms of maintaining TBT STCs, no one requested consultation against China in DSs. Thus, measures maintained by the Chinese government raised STC, but did not seemingly violate TBT agreements and provoked no action regarding DS. It might be the case that TBTs implemented by China could have been imposed in good faith and there might have been justifiable motivations behind them. ${ }^{16}$

\footnotetext{
${ }^{14}$ Page 80 of the report.

15 These disputes are available at the WTO website: http://www.wto.org/english/ tratop_e/dispu_e/dispu_agreements_index_e.htm?id=A22\#selected_agreement.

${ }^{16}$ There might be some reasons explaining this situation: firstly, because China implemented TBT measures on real grounds and on a non-discriminative basis that have had no impact on trade flows; secondly, because China is a very competitive country in the international market, the measures imposed have had no visible effect on imports to China. Thus, exporters are facing relatively minor problems and do not request for DS consultations.
} 
Table 3. Summaries of DS cases based on their respondents

\begin{tabular}{lcccccc}
\hline Respondent & Cases & Resolved & $\begin{array}{c}\text { Matched } \\
\text { STCs }\end{array}$ & Cited TBT Art. & $\begin{array}{c}\text { Average } \\
\text { Years Length }\end{array}$ & $\begin{array}{c}\text { Max Year } \\
\text { Length }\end{array}$ \\
\hline EU Countries & 20 & 14 & 11 & $2,5,6,7,8,9,12$ & 4.6 & 14.6 \\
USA & 11 & 11 & 7 & $2,5,6,7,8,12$, & 4.4 & 14.6 \\
Argentina & 4 & 2 & 1 & $2,2.2,5,12$ & 2.4 & 2.6 \\
$\begin{array}{l}\text { South } \\
\text { Korea }\end{array}$ & 4 & 4 & 4 & $2,5,6$ & 3 & 6.2 \\
Australia & 3 & 0 & 3 & $2.1,2.2$ & - & - \\
Mexico & 2 & 1 & 0 & $1,2,5$ & 2.7 & 2.7 \\
India & 1 & 0 & 1 & 2 & - & - \\
\hline Total & 45 & 32 & 27 & - & $\begin{array}{c}4.14 \text { (total } \\
\text { average) }\end{array}$ & \\
\hline
\end{tabular}

Source: WTO website and the STC database on TBT.

The United States of America is the second most frequent respondent for DSs; totalling 11 cases. South Korea is the fourth country in terms of the imposition of STCs on TBT, and the fourth member respondent for violation of the TBT agreement (four cases). Argentina, Australia, Mexico, and India represent the rest of the WTO members responding to violations of the TBT agreement within the DSM. Among all of these 7 groups of countries, Australia maintained the lowest number of TBT STCs in the data.

\section{Matching DS cases with the TBT data}

Figure 1 shows the trend of raised STCs in bars and that of DS cases in the marked line. Before 1999, these two trends were moving in opposite directions. From 1995-1999, the number of new STCs was gradually increasing, while DS cases were decreasing to zero. In 1999, 2004, 2005, 2006, and 2011, there were no requests for consultation within the DSM citing the TBT agreement. From 1999 until 2011, these two trends followed almost similar patterns. It is worth mentioning that the number of DS cases citing TBT agreements decreased erratically during 1995-2011.

Some of the DS cases have no references in the TBT STC database. Several explanations are possible: Firstly, the dates on which DS cases have been requested are mostly different from those of the related STCs 
being raised. In some cases, STCs (e.g. DS144) were raised at a later date; Secondly, occasionally disparity can be attributed to the fact that sometimes an STC is referring to multiple cases of DS (e.g. item number 304 might be related to DS434, DS435, and DS441); Thirdly, sometimes, a reverse case can also be observed when a special case of DS refers to multiple items of $\mathrm{STCs}^{17}$ (e.g. DS135 is related to items number 12, 22, and 25); Fourthly, some TBT cases of DS are not included in the TBT data, but are included in the SPS data (e.g. DS5 and DS20 are related to item number 1 of the SPS STC data; DS3 and DS41 are related in item number 2 of that data); Fifthly, there are many disputes (18 cases) that have not been found in the data or in the online TBT Information Management System of the WTO. They might not have been included in the data or have been suspended afterwards because the complainants have withdrawn their requests (e.g. DS72, DS210, and DS232).

Figure 1. Trends of DSs and TBT STCs

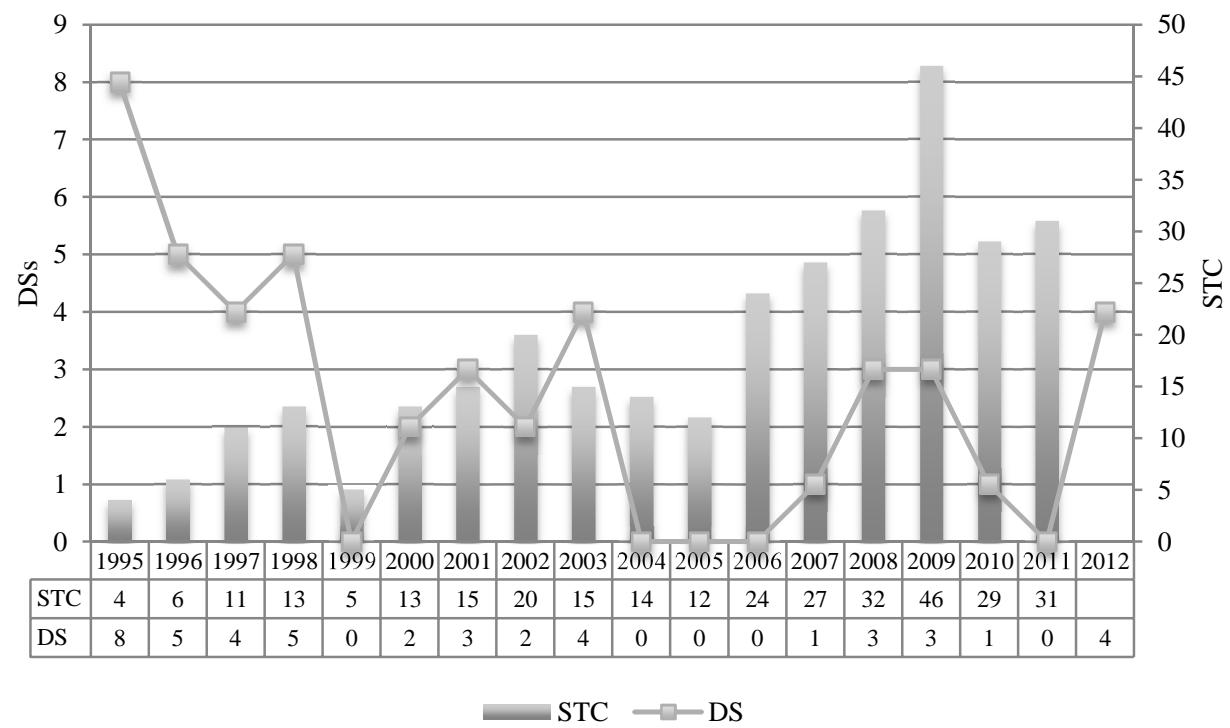

Source: STC database and the WTO website.

\footnotetext{
${ }^{17}$ The question of causality between STCs and DS is important. We will refer to this issue at a later stage.
} 
Some TBT complaints in DS cases have been rejected by the DS findings, which means that there was not sufficient evidence of violations of the TBT agreement. In many cases, the TBT agreement has been cited in addition to some other agreements. Obviously, only after the final acceptance of the Panel and the Appellate bodies' reports is it possible to conclude whether or not the TBT Agreement was violated. For instance, in DS56, the United States requested consultation with Argentina citing, inter alia, Article 2 of the TBT agreement. The Panel found violations of Article II and VIII of the GATT ${ }^{18}$ but did not find violations of the TBT agreement. Therefore, the citation of the TBT agreement in one's request for a panel does not necessarily mean that there was a violation of the TBT Agreement.

According to Table 3, more than two thirds of all cases have been resolved so far. Almost two thirds of these cases have been found in the STC data on TBT. Article 2 of the TBT agreement has been the most frequently cited among all of the articles of the agreement. The second column to the left shows the average years length between the date of the consultation request and the date of the report's acceptance. It took about 4.14 years on average for disputes to be resolved. The last column of this table shows the maximum duration between the consultation request and the case resolution. It took a long time to solve the cases in which the EU and the USA were involved; in some cases taking more than 14 years.

\section{Time consuming procedures within the DSM}

A lengthy dispute procedure from the request for consultation until the DS resolution can be costly. Firstly, there are the costs for the complainant countries that are exporting to the countries imposing TBT measures (the costs of decreased exports). For instance, Canada requested consultation with the United States in December 2008 (DS384) concerning certain mandatory country of origin labelling (COOL) provisions. 'Meat of swine, fresh or chilled - carcasses and half carcasses' was one of the products covered by this dispute ${ }^{19}$. During the procedures, exportation of this product from Canada to the USA dropped from 13.68 million USD in 2007 to

\footnotetext{
${ }^{18}$ According to the WTO website: http://www.wto.org/english/tratop_e/dispu_e/cases_e /ds56_e.htm, the Appellate Body upheld the Panel's report with some modifications including that: "The Panel found that the minimum specific duties imposed by Argentina on textiles and apparel are inconsistent with the requirements of Article II of GATT, and that the statistical tax of three per cent ad valorem imposed by Argentina on imports is inconsistent with the requirements of Article VIII of GATT." The Appellate Body (AB) upheld the Panel's findings.

${ }^{19}$ According to the matched item in the TBT STC data, item number 91.
} 
5.12 million USD in 2008, and finally to 3,000 USD in $2012^{20}$. After the findings of the DSB, the USA made a commitment to implement the rulings until May 2013. Thus, until the date of the dispute resolution and amendments by the US government, there were significant costs incurred by Canadian exporters of swine meat.

Secondly, long lasting consultations impose a high cost to the DSB analyzing the case. For example, in case DS144 - an unresolved case and apparently similar case to DS384 - the dispute took more than 14 years to be completed, in which violations of Article 2.1 of the TBT agreement were analysed by the DSB. During this time, the US was discriminating against products imported from Canada in comparison to similar domestic products, incurring high costs on trade and the costs of the analysis within the DSB.

The Understanding on rules and procedures governing the settlement of disputes provides the timetable for the dispute settlement mechanism (DSM). According to the Understanding, from the time a case is requested for consultation, it should not take more than one year until the Panel's report becomes a ruling. If one side appeals, it should not take more than three additional months for the ruling of the Appellate Body (AB). However, the DSM Agreement has some flexibility and countries can resolve cases themselves through consultations at any stage.

Table 4 shows disputes with the total duration until the final resolutions of the cases. There are still 8 DS cases in consultation without the establishment of a panel body. The second row of this table shows the cases that, according to the WTO website, were formally in consultation by the end of 2012. All of these six cases took a long time to be resolved (see comments to the second row $)^{21}$. Of course, long lasting consultations usually mean that both sides of the conflict are trying to reach an agreement and the violation of WTO agreements is not evident ${ }^{22}$. The last five rows show that there are also many DS cases with procedures lasting for more than one year. Sometimes the duration for adopting DSB findings was very long. For instance, the last row shows two cases responded to by the EU in which the $\mathrm{AB}$ circulated its findings within less than 2 years of the request being made, and the implementation of the Appellate ruling took more than 12 years.

${ }^{20}$ This data is collected from UN COMTRADE, available at: http://comtrade.un.org/.

${ }^{21}$ It seems that these cases are resolved thanks to analysis of the linkages between the TBT and SPS datasets.

${ }^{22}$ It is worth mentioning that on the WTO website there is no updated information for these old cases, and these disputes with no updates seem to have been resolved. 
Table 4. TBT DS cases and their duration until their final resolution

\begin{tabular}{|c|c|c|c|}
\hline DS conclusion & $\begin{array}{l}\text { No. } \\
\text { DSs }\end{array}$ & DS Cases & Comments \\
\hline $\begin{array}{l}\text { In consulta- } \\
\text { tion without } \\
\text { panel }\end{array}$ & 8 & $\begin{array}{l}137,203 \\
233,263 \\
279,435 \\
441,446\end{array}$ & \\
\hline $\begin{array}{lr}\text { In } & \text { consulta- } \\
\text { tion } & \text { but } \\
\text { seems } & \text { re- } \\
\text { solved } & \end{array}$ & 6 & $\begin{array}{l}3,41,61, \\
100,134, \\
144\end{array}$ & $\begin{array}{l}\text { DS3 and DS41 are resolved without panel establishment } \\
\text { after more than } 5 \text { years (according to the STC database on } \\
\text { SPS). DS61 seems to be resolved after about } 5 \text { years with } \\
\text { DS58 (according to the WTO website }{ }^{23} \text { ). DS100 seems to } \\
\text { be resolved with related cases like DS384 and DS386 after } \\
\text { more than } 14 \text { years since its request. DS134 seems to be } \\
\text { resolved after more than } 3 \text { years with DS210. DS144 } \\
\text { seems to be resolved after more than } 14 \text { years along with } \\
\text { the related cases DS384 and DS386. }\end{array}$ \\
\hline $\begin{array}{l}\text { In consulta- } \\
\text { tion after } \\
\text { panel estab- } \\
\text { lishment }\end{array}$ & 5 & $\begin{array}{l}369,389, \\
400,401, \\
434\end{array}$ & \\
\hline $\begin{array}{l}\text { Withdrawn } \\
\text { without panel } \\
\text { before } 1 \text { year }\end{array}$ & 3 & $5,20,85$ & \\
\hline $\begin{array}{l}\text { Withdrawn } \\
\text { after } 1 \text { to } 2 \\
\text { years by } \\
\text { request }\end{array}$ & 5 & $\begin{array}{l}7,12,14, \\
151,210\end{array}$ & $\begin{array}{l}\text { DS7, DS12, and DS14 have been resolved by mutual } \\
\text { agreements before the Panel's reports. DS7's mutual } \\
\text { agreement took less than one year after the request was } \\
\text { made. }\end{array}$ \\
\hline $\begin{array}{l}\text { Cases that } \\
\text { last from } 2 \text { to } \\
3 \text { years }\end{array}$ & 10 & $\begin{array}{l}72, \quad 77, \\
232,290, \\
2,4,56, \\
135,231, \\
206\end{array}$ & $\begin{array}{l}\text { DS72, DS77, and DS232 were withdrawn before the } \\
\text { Panel's reports. DS290 was concluded by the Panel's } \\
\text { report. The rest of the cases have been concluded by the } \\
\text { AB's report. }\end{array}$ \\
\hline $\begin{array}{l}\text { Cases that } \\
\text { last from } 3 \text { to } \\
5 \text { years }\end{array}$ & 4 & $\begin{array}{l}291,381, \\
384,386\end{array}$ & $\begin{array}{l}\text { DS291 was resolved by the Panel's report after more than } \\
3 \text { years. The rest of the cases were resolved by the AB's } \\
\text { findings after more than three years, but the adaptation } \\
\text { would take place after more than } 4 \text { years. }\end{array}$ \\
\hline $\begin{array}{l}\text { Cases that } \\
\text { last from } 5 \text { to } \\
7 \text { years }\end{array}$ & 2 & 292,293 & $\begin{array}{l}\text { These cases reached mutual agreements after more than } 6 \\
\text { years, but the Panel's report was circulated about } 3 \text { years } \\
\text { after the requests were made. }\end{array}$ \\
\hline $\begin{array}{l}\text { Cases that } \\
\text { last from } 13 \\
\text { to } 15 \text { years }\end{array}$ & 2 & 26,48 & $\begin{array}{l}\text { DS26 and DS } 48 \text { reached mutual agreements after more } \\
\text { than } 13 \text { and } 14 \text { years respectively, but the AB's reports } \\
\text { were circulated after } 2 \text { and one and a half years respective- } \\
\text { ly after the requests were made. }\end{array}$ \\
\hline
\end{tabular}

Source: WTO website and own analysis.

It appears that the DSM is working less expeditiously in comparison to the provisions in the Understanding. There are only two DS cases (DS4 and DS2) leading to the AB's findings concluded within 15 months of the first

${ }^{23}$ Available at: http://www.wto.org/english/tratop_e/dispu_e/cases_e/ds61_e.htm. 
request for consultation. The $\mathrm{AB}$ circulated its findings for 5 cases between 15 and 24 months after the date that the request had been made, among which, two of them, (DS26 and DS48). The rest of the AB's findings were circulated more than about 3 years after the first requests for consultation. Thus, it is important to highlight the significant costs incurred by the complainant countries, in addition to the analytical and judicial costs incurred by the WTO Secretariat assisting DS bodies.

\section{Panel and Appellate Bodies' (AB) Reports}

In 28 of the 45 requests for consultation, citing the TBT agreement, the complaining countries requested the establishment of a panel. For 25 of them, the panels were established and for 19 of them, the panels circulated their reports. After the Panel's reports, 8 cases were concluded by mutual agreement between the parties. 11 other cases led to the establishment of the AB because one of the parties appealed. By the end of 2012, AB provided its findings for all 11 cases listed in the reports, after which the parties reached mutual agreements ${ }^{24}$.

Table 5 shows the violations of WTO agreements confirmed by the final findings of the Panel and/or AB's reports. When the panel report is sent to the $\mathrm{AB}$, the final conclusions of the $\mathrm{AB}$ (and not of the Panel report) should be adopted by the DSB. Cases in the left column have been found in the STC database on TBT. Only five out of the 19 cases analyzed by the Panel and/or the $\mathrm{AB}$ have been confirmed as violations of the TBT agreement. Thus, among 45 DS cases citing the TBT Agreement, only 11\% (5 out of 45) of them have been TBT violations, confirmed by the AB. These simple statistics demonstrate how complicated the evaluations of TBT measures can be. DS231 covers only 3 observations, DS381 covers 13 observations, DS384 covers 28 observations, DS386 covers 34 observations, and DS406 covers only 1 observation in the TBT STC data. Even though the scope of trade flows covered by the disputes includes a limited number of products, these DS cases were important for the exporters of goods covered by the TBT's.

\footnotetext{
${ }^{24}$ As mentioned earlier, DS100 did not lead to the establishment of a panel, but it seems that it is a similar case to DS384 that was concluded by the Appellate findings.
} 
Table 5. Violated Articles Approved by the Panel or the Appellate Body

\begin{tabular}{|c|c|c|c|c|c|}
\hline DS & Respondent & Concluded Violated Art. & DS & Respondent & $\begin{array}{c}\text { Concluded } \\
\text { Violated Art. }\end{array}$ \\
\hline 406 & USA & $2.1,2.9 .2,2.12 \mathrm{TBT}$ & 72 & EU & $\begin{array}{l}\text { Withdrawal of } \\
\text { Request }\end{array}$ \\
\hline 386 & USA & $2.1 \mathrm{TBT}$ & 56 & Argentina & $\begin{array}{l}\text { II, and VIII of } \\
\text { GATT }\end{array}$ \\
\hline 384 & USA & $2.1 \mathrm{TBT}$ & 48 & $\mathrm{EU}$ & $\begin{array}{l}3.3 \text {, and } 5.1 \text { of } \\
\text { SPS }\end{array}$ \\
\hline 381 & USA & $2.2 \mathrm{TBT}$ & 26 & EU & $\begin{array}{l}3.3 \text {, and } 5.1 \text { of } \\
\text { SPS }\end{array}$ \\
\hline 293 & EU & $\begin{array}{l}\text { Annex } \mathrm{C}(1)(\mathrm{a}), 8,5.1,5.5 \text {, and } 2.2 \text { of } \\
\text { SPS }\end{array}$ & 14 & EU & $\begin{array}{l}\text { Withdrawal of } \\
\text { Request }\end{array}$ \\
\hline 292 & EU & $\begin{array}{l}\text { Annex } \mathrm{C}(1)(\mathrm{a}), 8,5.1,5.5 \text {, and } 2.2 \text { of } \\
\text { SPS }\end{array}$ & 12 & $\mathrm{EU}$ & $\begin{array}{l}\text { Withdrawal of } \\
\text { Request }\end{array}$ \\
\hline 291 & EU & Annex $\mathrm{C}(1)(\mathrm{a}), 8,5.1,5.5$, and $2.2 \mathrm{SPS}$ & 7 & EU & $\begin{array}{l}\text { Withdrawal of } \\
\text { Request }\end{array}$ \\
\hline 290 & EU & Annex $\mathrm{C}(1)(\mathrm{a}), 8,5.1,5.5$, and $2.2 \mathrm{SPS}$ & 4 & US & III:4 of GATT \\
\hline 231 & $\mathrm{EU}$ & 2.4 TBT & 2 & US & III:4 of GATT \\
\hline 135 & $\mathrm{EU}$ & III:4 GATT & & & \\
\hline
\end{tabular}

Note: The shaded areas are the cases concluded by the Panel and the white areas are the ones concluded by the Appellate Body (AB).

Source: WTO website.

The principle of non-discrimination (Article III) is one of the key provisions of the GATT/WTO system. Its equivalent in the TBT agreement is Article 2.1 that states: "members shall ensure that in respect of technical regulations, products imported from the territory of any Member shall be accorded treatment no less favorable than that accorded to like products of national origin and to like products originating in any other country." When it is proved that Article 2.1 has been violated, it should be clarified whether or not the policy measure was introduced to pursue protection of domestic industries rather than protection of human health, safety, animal or plant life, or the environment, i.e. in accordance with WTO regulations. However, clear conclusions on this issue have been presented in only four cases out of the 45 DS requests.

In the case of DS406, the AB report stated that the US violated articles 2.9.2 and 2.12 of the TBT agreement. It concluded that the imposition of the TBT measure by the US violated transparency requirements. In addition to the above-mentioned four cases in which Article 2.1 was violated, there have been 14 other requests for consultation under Article 2.1 of the TBT 
agreement. The Panel has analyzed four of them ${ }^{25}$ and found no violation of the TBT agreement. Ten other cases have not been submitted to the Panel or the AB's analyses in order to find whether they were violations of this article. Seven of these cases are still in consultation, and three others were mutually agreed before the submission of the Panel report. In the case of DS231, the AB found that TBTs maintained by the EU were inconsistent with Article 2.4 and recommended that the measures be brought into conformity with the EC's obligations under this article. Thus, despite many arguments presented in the economic literature, there are only a few cases in which a violation of the non-discrimination principle was found by the DSM reports.

\section{Econometric Analysis of the Linkages Between Dispute Settlements and STCs}

As discussed above, we have found few direct linkages between the raised TBT STCs and DS cases citing the TBT agreement. In this section, similar to the approach used by Busch and Reinhardt (2003), we will use econometrics to find evidence of such linkages. Let us assume that a DS case that is requested by the exporting country $j$ (complainant and/or third party) of the product category $h$ to the importing country $i$ (respondent) is a function of STCs raised by $j$ on the TBT imposed by $i$ on product $h\left(S T C_{i j h t}\right)$, applied tariffs imposed by $i$ against product $h$ from $j\left(T_{i j h t}\right)$, share of product imports from $j$ in total product imports by $i\left(S M_{i j h t}\right)$, and the size of the two partners $(Y)$ :

$$
D S_{i j h t}=S T C_{i j h t}^{\beta_{1}} T_{i j h t}^{\beta_{2}} S M_{i j h t}^{\beta_{3}} Y_{i t}^{\beta_{4}} Y_{j t}^{\beta_{5}}
$$

In order to analyze the impact of TBT STCs on the occurrence of DS cases citing the TBT agreement we will use an unbalanced panel database gathered from three data sources encompassing all WTO members from 1995-2011. By taking the logarithmic form of the two sides of equation (1), we can have the following equation suitable for running regressions:

$$
D S_{i j h t}=\exp ^{\beta_{1} S T C_{i j h t}+\beta_{2} T_{i j h t}+\beta_{3} S M_{i j h t}+\beta_{4} Y_{i t}+\beta_{5} Y_{j t}+\vartheta_{i h j}+\mu_{t}+\varepsilon_{i j h t}}
$$

${ }^{25}$ DS290, DS291, DS292, DS293. 
Where the dependent variable $D S_{i j h t}$ is the number of DS cases responded to by the importer country $i$ that is complained about by country (or third parties) $j$ on product $h$ at a 2-digit level of the HS at time $t$. The information on this variable is gathered from the WTO website covering all DS cases citing the TBT agreement during 1995 to 2011. This variable is a count variable that takes discrete values. The maximum value of this variable in the sample is 2, referring to DS3, which was responded to by the Republic of Korea, and to DS cases 290 and 291, which were responded to by the $\mathrm{EU}^{26}$.

$S T C_{i j h t}$ is the TBT STC on product h maintained by the importer country $i$ raised by partner country $j$ at time $t$, which is obtained from the database provided by the WTO secretariat.

$S M$ refers to the share of product imported from the partner country relative to the total imports of that product, in logarithmic form. In the majority of the requests for consultation within the DSM, the complainant and third party countries are motivated to make their requests due to the significant share of their exports within the total import of the respondent country. Therefore, we expect to find a positive relationship between this control variable and the occurrence of a DS case. The data on bilateral imports of products is obtained from the WITS website ${ }^{27}$.

$T_{i j h t}=\ln \left(1+t_{i j h t}\right)$, where $t_{i j h t}$ stands for the average tariff imposed by the importer country $i$ on all subcategories of a 2-digit level of Harmonized System product $h$ imported from the partner country $j$. In order to have a suitable dataset covering most observable tariffs, we gather tariff data from three sources. First, we use effectively applied tariff rates (AHS) compiled by WITS. Second, where AHS is missing, we use the bilateral preferential tariff rates (PRF). Third, where both AHS and PRF are missing, we use unilateral MFN rates. Ad-valorem tariff rates estimated by the UNCTAD methodology (UNCTAD/WTO, 2012).

Regulations imposed within TBT notifications are usually permanent rules affecting trade during the long run. A similar hypothesis can be argued for tariff rates. Besides, the share of imports, or being a major exporter to a country in a previous year, can be a motivation for a request for con-

${ }^{26}$ There are some DS cases such as DS291, DS292, and DS293, for which only the complainant countries are different, while they are also third parties in the two other cases. Hence, such DS cases are considered in our analysis as one unique DS case. Therefore, the maximum value of the DS variable is 2, meaning that for DS290 and DS291 (DS292 and DS293) two cases exist responded to by the EU for a specific product in 2003.

${ }^{27}$ Can be found at: https://wits.worldbank.org/. 
sultation. Therefore, in our analysis, we also consider the lag of these three variables in separate specifications.

The trade policy of a large country may have more significant implications than that of a small country. Obstacles imposed by TBT regulations at the focus of a DS case can draw more attention if the maintaining importer country is a large country. On the other hand, controlling for trade shares, a small country that has fewer trade partners and faces a restrictive TBT regulation, can be more affected than a large country. Therefore, a small country is potentially more vulnerable to an unnecessary obstacle and more motivated to initiate a dispute. In order to control for the size of both trade partners, we include the logarithmic form of real Gross Domestic Product (GDP) of the two countries. The data for GDP is collected from the World Development Indicator database provided by the World Bank ${ }^{28}$.

Due to the heterogeneity of countries and products, estimation of equation (2) might be biased. Where $\varepsilon_{i j h t}$ is the error term, unobserved effects and heteroskedasticity are the issues being controlled using country-pairproduct $\vartheta_{i j h}$ and year effects $\mu_{t}$. Since the dependent variable is count discrete data, we apply Maximum Likelihood Poisson regression to achieve unbiased results. To control for fixed effects, we use a Fixed Effect (FE) robust Poisson estimator to attain the most consistent unbiased regressions. $^{29}$

Strict exogeneity of independent variables is the main assumption for having consistent estimates by FE Poisson. However, this assumption may be violated if there is a dual causality between the DS cases and the explanatory variables. For instance, a DS case on a certain product might possibly reduce the number of STCs raised on TBTs on the given product as the ongoing consultation might induce stronger cooperation and better information between the trade partners. This leads to the underestimation of the effect of TBT STC on the occurrence of DS case. A similar intuition can be argued for the share of imports from the trade partner causing underestimation of its impact on the occurrence of the dependant variable.

In order to deal with the endogeneity bias, as robustness checks we use exponential Generalized Method of Moments (GMM) estimation that is

28 Can be found at: http://data.worldbank.org/data-catalog/world-developmentindicators.

${ }^{29}$ It is important to mention that FE Poisson regression will drop some observations from the dataset if no variation within the dependent variable is detected during the period. Firstly, single observations within each group of individual (i.e. product-paired-country) are dropped. Secondly, if there are no changes of the dependent variable within a specific group during the period, the group will be completely dropped. This omission of a variable is consistent with the econometric specification of the Poisson FE method, giving robust results 
equivalent to Poisson estimation with endogenous regressors. We use a set of exogenous variables as instruments that will be also confirmed by the Hansen's J test statistics. As instruments for TBT STCs that are bilaterally endogenous in the model, we apply TBT and SPS that are unilaterally imposed against all partners, in addition to Specific Safeguards (SSG) that are mainly imposed temporarily to restrict the imports of a product protecting the domestic industry within the WTO legislations. The data on these trade policy measures are gathered from the Integrated Trade Intelligence Portal (I-TIP) provided by the WTO. Moreover, average maximum bound tariff rate is used as another instrument that is predetermined by the schedules of concessions within the WTO. Additionally, tariff and share of imports in the previous period are used as instruments that are assumed uncorrelated with the contemporaneous error components of the model. Population (P) and household consumption expenditures (HC) are used as instruments for GDP. While GDP might be affected by the DS case through import channels, $\mathrm{P}$ and $\mathrm{HC}$ are driven by domestic independent factors. Iterated GMM with heteroskedasticity-autocorrelation-consistent (HAC) weight matrix proposed by Newey and West (1994) is used to control for the possible misspecifications of the model using lags of variables. Moreover, countrypair-product clustering of the standard errors is used to give robust results.

\section{Estimation Results}

Table 6 presents the FE Poisson regression results of the model. Incidence Rate Ratio (IRR) is presented as the estimated coefficients of the variables. Thus, a coefficient bigger than one indicates the positive impact of the given variable on the dependent variable, and a coefficient smaller than one indicates a negative impact. Within all of the specifications, there is a statistically significant positive relationship between disputes and current TBT STCs. Having country sizes in the estimation (models 4 through 7), a new STC raised by a partner country on a TBT imposed by an importer on a specific category of products is expected to increase the probability of a DS case being requested by the partner on the given product by about 1.60 times. However, TBT STCs raised in the previous year $\left(\mathrm{STC}_{\mathrm{t}-1}\right)$ are statistically insignificant but decreasing the probability of an occurrence of such a DS case, holding the current TBT STCs and other variables constant.

The possible explanation of these results can be as follows. Usually, TBT regulations are of a long lasting nature. The significant effects of regulations are generally observed instantly after their imposition. After a period of time, producers can adapt the technical characteristics of their prod- 
ucts to meet new regulations and can continue exports to the foreign market. This means that a TBT STC that is raised in a previous year does not cause the same problems that it had provoked in the beginning of the period. As mentioned earlier, the implementation of standards, increasing market transparency, can have a positive impact on trade flows in the long run. Therefore, it is likely that after TBT STC notification, the demand for consultation after some period of time would decrease, as the producers facing those TBTs have already complied with those standards. Thus, we can state that FE Poisson estimations confirm the hypothesis that the imposition of new TBT STCs can act as an early warning for future DS cases.

Table 6. FE Poisson Regression Results (IRR)

\begin{tabular}{|c|c|c|c|c|c|c|c|}
\hline Dep: DS $_{\text {ijht }}$ & 1 & 2 & 3 & 4 & 5 & 6 & 7 \\
\hline $\mathrm{STC}_{\mathrm{ijht}}$ & $\begin{array}{c}1.59 * * * * \\
(0.21)\end{array}$ & $\begin{array}{c}1.59 * * * * \\
(0.21)\end{array}$ & $\begin{array}{c}1.59 * * * \\
(0.21)\end{array}$ & $\begin{array}{c}1.60 * * * * \\
(0.21)\end{array}$ & $\begin{array}{c}1.60^{* * *} \\
(0.21)\end{array}$ & $\begin{array}{c}1.60 * * * * \\
(0.21)\end{array}$ & $\begin{array}{c}1.60 * * * * \\
(0.21)\end{array}$ \\
\hline$T_{i j h t}$ & & $\begin{array}{c}0.85 \\
(0.14)\end{array}$ & $\begin{array}{c}0.85 \\
(0.14)\end{array}$ & $\begin{array}{c}0.82 \\
(0.14)\end{array}$ & $\begin{array}{c}0.81 \\
(0.14)\end{array}$ & $\begin{array}{c}1.25 \\
(0.21)\end{array}$ & $\begin{array}{c}1.24 \\
(0.21)\end{array}$ \\
\hline $\mathrm{SM}_{\mathrm{ijht}}$ & & & $\begin{array}{c}1.03 * \\
(0.017)\end{array}$ & $\begin{array}{c}1.03^{*} \\
(0.017)\end{array}$ & $\begin{array}{c}1.03^{*} \\
(0.017)\end{array}$ & $\begin{array}{c}1.03^{*} \\
(0.017)\end{array}$ & $\begin{array}{l}1.04 * * \\
(0.019)\end{array}$ \\
\hline $\mathrm{Y}_{\mathrm{jt}}$ & & & & $\begin{array}{c}1.30 \\
(0.27)\end{array}$ & $\begin{array}{c}1.32 \\
(0.27)\end{array}$ & $\begin{array}{c}1.34 \\
(0.28)\end{array}$ & $\begin{array}{c}1.36 \\
(0.29)\end{array}$ \\
\hline $\mathrm{Y}_{\mathrm{it}}$ & & & & $\begin{array}{c}0.51^{* * *} \\
(0.15)\end{array}$ & $\begin{array}{c}0.51^{* * *} \\
(0.15)\end{array}$ & $\begin{array}{c}0.48^{* * *} \\
(0.14)\end{array}$ & $\begin{array}{c}0.48^{* * *} \\
(0.14)\end{array}$ \\
\hline STC $_{\text {ijht-1 }}$ & & & & & $\begin{array}{c}0.78 \\
(0.12)\end{array}$ & $\begin{array}{c}0.79 \\
(0.12)\end{array}$ & $\begin{array}{c}0.79 \\
(0.12)\end{array}$ \\
\hline $\mathrm{T}_{\mathrm{ijht}-1}$ & & & & & & $\begin{array}{c}0.30 * * * * \\
(0.067)\end{array}$ & $\begin{array}{c}0.29 * * * * \\
(0.066)\end{array}$ \\
\hline $\mathrm{SM}_{\mathrm{ijht}-1}$ & & & & & & & $\begin{array}{c}0.97 \\
(0.017) \\
\end{array}$ \\
\hline $\mathrm{N}$ & 62919 & 62919 & 62919 & 62919 & 62919 & 62919 & 62919 \\
\hline AIC & 13548.0 & 13549.5 & 13547.5 & 13545.1 & 13542.2 & 13517.0 & 13516.7 \\
\hline BIC & 13692.8 & 13703.4 & 13710.4 & 13726.1 & 13732.3 & 13716.0 & 13724.8 \\
\hline Year Effects & Yes & Yes & Yes & Yes & Yes & Yes & Yes \\
\hline
\end{tabular}

Exponentiated coefficients reported indicate Incidence-Rate Ratios (IRR)

Robust standard errors in parentheses

$* p<0.10, * * p<0.05, * * * p<0.01$

Source: own estimations.

Share of imports is statistically significant at a $10 \%$ level, indicating a positive influence on the dependant variable. This suggests that a major exporter is evidently more eager to request a complaint against a given importer than a smaller exporter is. Hence, the share of imports from trade partner increases - in a statistically significant way - the probability of a trade partner filing a case. 
As discussed earlier, there is a possible substitutability between tariffs and NTMs. In our specifications (columns 2 through 7), we control for both of them. The results show a statistically insignificant relationship between current tariffs and the occurrence of a TBT DS case. Despite statistic insignificance, this effect changes from negative to positive while including lag of tariffs (columns 6 and 7). Since the tariffs contained in the schedules of concessions are bound for WTO members, and since the DS cases under the study are related to the TBT issues rather than tariff issues, such results are not unexpected. In fact, a $1 \%$ higher tariff faced by an exporter on a given product in previous period reduces the probability of requesting a DS case citing TBT agreement on that given product by a factor of about 0.29 , holding other variables constant (model 7).

Similar to the results by Busch and Reinhardt (2003), the GDP of the exporter has no statistically significant relationship with a DS case. Unlike their result, we find statistically significant relationship between the GDP of importer and responding a DS case. Results, suggest that when the GDP of the importer decreases during time by $1 \%$, the probability of responding to a DS case citing TBT agreement increases by factor of 2.08 (i.e. $\frac{1}{0.48}$ ). This might hint at a possible motive for violating the TBT agreement during economic downturns when the GDP decreases.

Unlike Bayesian information criterion (BIC), Akaike information criterion (AIC) indicate that models are improving from 2 through 7 by inclusion of an additional explanatory variable. Nevertheless, both test statistics show that inclusion of tariffs does not improve model (1) as tariffs are statistically insignificant.

Table 7 presents the Poisson GMM regression results of the 7 specifications similar to those presented in Table 5. In all the specifications, large pvalues of Hansen's J test do not reject the hypothesis of exogenous instruments pointing at unbiased GMM estimations. Very large and statistically significant IRR coefficients of TBT STCs indicate underestimation of STC effects on the occurrence of DS obtained from FE Poisson regressions. In fact, controlling for the endogeneity of TBT STCs using TBT, SPS, and SSG notifications, the occurrence of a DS case on bilateral product flow increases by the factor of 33.3 when an additional TBT STC is raised on that product flows holding all other variables constant (model 7). Among all regressions, we find positive influence of previous TBT STCs on the occurrence of DS cases only in model 7 of the GMM Poisson regressions controlling for other variables and endogeneity issues. This again confirms the positive linkages between TBT STCs and DS cases citing TBT agreement. 
Controlling for all other variables in model 7 , and instrumenting with maximum bound tariff rates, the occurrence of a DS case citing TBT agreement on a bilateral product flow is decreased by the factor of 0.017 when tariffs are increased by $1 \%$. A negative impact was observed for the lag of tariffs in FE Poisson regressions not controlling for the simultaneous bias. In the GMM regressions, tariffs in the previous period have no statistically significant impact on the dependent variable. However, while not controlling for other variables, model 2 indicates that higher tariffs are linked with higher probability of a DS case on a bilateral product flow. This bias is corrected after including the imports share, which are affected by tariffs.

Table 7. Poisson GMM Regression Results (IRR)

\begin{tabular}{|c|c|c|c|c|c|c|c|}
\hline Dep: DS $_{i j h t}$ & 1 & 2 & 3 & 4 & 5 & 6 & 7 \\
\hline STC $_{\mathrm{ijht}}$ & $\begin{array}{c}31.3 * * * * \\
(5.40)\end{array}$ & $\begin{array}{c}33.3^{* * * *} \\
(5.82)\end{array}$ & $\begin{array}{c}18.5^{* * * *} \\
(7.71)\end{array}$ & $\begin{array}{c}44.1 * * * * \\
(15.0)\end{array}$ & $\begin{array}{c}43.5^{* * *} \\
(15.9)\end{array}$ & $\begin{array}{c}42.6 * * * * \\
(15.8)\end{array}$ & $\begin{array}{c}33.3 * * * \\
(10.6)\end{array}$ \\
\hline $\mathbf{T}_{\mathrm{ijht}}$ & & $\begin{array}{c}2.02 * * * \\
(0.44)\end{array}$ & $\begin{array}{c}1.14 \\
(0.48)\end{array}$ & $\begin{array}{l}0.53^{*} \\
(0.18) \\
\end{array}$ & $\begin{array}{c}0.52 \\
(0.24)\end{array}$ & $\begin{array}{c}0.67 \\
(1.38)\end{array}$ & $\begin{array}{c}0.017 * * * \\
(0.026)\end{array}$ \\
\hline $\mathbf{S M}_{\mathrm{ijht}}$ & & & $\begin{array}{c}2.13 * * * \\
(0.21)\end{array}$ & $\begin{array}{c}2.94 * * * \\
(0.31)\end{array}$ & $\begin{array}{c}2.94 * * * \\
(0.32)\end{array}$ & $\begin{array}{c}2.92 * * * * \\
(0.32)\end{array}$ & $\begin{array}{c}4.38 * * * \\
(0.73)\end{array}$ \\
\hline $\mathbf{Y}_{\mathbf{j t}}$ & & & & $\begin{array}{c}0.64 * * * \\
(0.029)\end{array}$ & $\begin{array}{c}0.64 * * * \\
(0.029)\end{array}$ & $\begin{array}{c}0.64 * * * \\
(0.029)\end{array}$ & $\begin{array}{c}0.76^{* * * *} \\
(0.030)\end{array}$ \\
\hline$\overline{Y_{\text {it }}}$ & & & & $\begin{array}{c}0.83 * * * \\
(0.039)\end{array}$ & $\begin{array}{c}0.83^{* * * *} \\
(0.041)\end{array}$ & $\begin{array}{c}0.83 \text { *** } \\
(0.041)\end{array}$ & $\begin{array}{c}0.94 \\
(0.057)\end{array}$ \\
\hline STC $_{\text {ijht-1 }}$ & & & & & $\begin{array}{c}1.08 \\
(0.46)\end{array}$ & $\begin{array}{c}1.07 \\
(0.44)\end{array}$ & $\begin{array}{c}4.11 * * * \\
(1.12)\end{array}$ \\
\hline$T_{i j h t-1}$ & & & & & & $\begin{array}{c}0.83 \\
(1.42) \\
\end{array}$ & $\begin{array}{c}4.68 \\
(4.89) \\
\end{array}$ \\
\hline $\mathbf{S M}_{\mathrm{ijht}-1}$ & & & & & & & $\begin{array}{c}0.46^{* * * *} \\
(0.024)\end{array}$ \\
\hline $\begin{array}{l}\mathbf{N} \\
\text { Hansen's J } \\
\text { p-value }\end{array}$ & 62919 & 62919 & 62919 & 62919 & 62919 & 62919 & 62919 \\
\hline
\end{tabular}

Exponentiated coefficients reported indicate Incidence-Rate Ratios (IRR)

Robust standard errors in parentheses

$* p<0.10, * * p<0.05, * * * p<0.01$

Source: own estimations.

As mentioned earlier, in the presence of dual causality between the dependent variable and import values, the effect of share of imports (SM) is underestimated, which can be observed comparing the FE Poisson results with the GMM results. Moreover, including the lag of this variable in model 7 indicates that larger share of imports from the exporter in the current period is largely related to the occurrence of the DS case when the previous 
imports share was relatively smaller. In fact, if the previous imports share were larger, the probability of having a DS case requested by the trade partner would be smaller.

Similar to FE Poisson results, larger GDP of the importer is related to a lower probability of responding to a DS case focused on the 2-digit bilateral flow. Moreover, GMM Poisson results show a similar relationship between the GDP of the exporter and the probability of requesting for a DS consultation. In fact, the statistically significant coefficient of the exporter's real GDP suggests that a $1 \%$ decrease in the GDP of the exporter is linked with a higher probability of requesting a complaint citing TBT agreement by that country for a factor of 1.32 times (i.e. $\frac{1}{0.76}$ ). This intuitively means that a smaller country is more vulnerable than a larger country to the prohibitive trade policies of a given trade partner.

\section{Conclusions}

In this paper, we present a summary of the STC database on TBT. The STC database is a useful tool increasing transparency of TBT measures and reducing the asymmetry of information. The descriptive analysis of linkages between DS cases and the TBT STC database is based on matching information from both sources. Out of 45 requests for consultation in the DSM for violation of the TBT agreement during 1995-2011, 27 cases were found in the STC data as well; among which four cases were found in the SPS STC database. There are 19 cases in the TBT STC database that are related to 23 disputes. The probable reasons for the dissimilarity between the trends of the STCs and the initiated disputes on TBT are discussed in the paper. Gaps between the dates of the raised concerns on TBT and the requested cases in the DSM, multiple cases of DS relating to one STC, and multiple items of STC relating to one DS case, are probably the main reasons for such dissimilarities.

According to the citations in the DS cases, in the Panel's and the Appellate Body's (AB's) reports, article 2 of the TBT agreement was the most frequently violated article in all cases. In 16 cases, Article 2.1 of the TBT agreement was cited and it was the main issue of some the AB's reports. In fact, discriminative aspects of the TBTs imposed by some governments have led to complaints by other members, leading to requests for consultation. Even though all WTO members demand transparency in trade policies, some TBTs are still having discriminatory effects in international trade. The European Communities and the United States of America are 
maintaining most of the STCs raised on TBTs and they are the respondent for most of the DS cases. In 45 cases of disputes citing the TBT agreement, the DS body has proved in its findings that EU members have violated the TBT agreement once and violated other WTO agreements for 8 times. USA has violated the TBT agreement four times and other WTO agreements twice. While China is the second most cited country for maintaining TBT STCs, there have been no consultations requested against this country under the DSM regime. Nevertheless, the EU as the first and the US as the third placed country imposing TBT STCs have responded to the largest numbers of DS cases citing the TBT agreement. It is worth mentioning that countries raising STCs are mostly quite reluctant to initiate cases in the DSM in order to maintain frictionless multilateral trade with their partners. In other words, WTO members probably prefer bilateral and multilateral negotiations under the TBT Committee, rather than starting costly disputes.

Based on a simple descriptive analysis, we find no genuine evidence that STCs provide a good foresight for future disputes on TBTs. However, the econometric analysis allows us to draw more precise conclusions at traded products under disputes. In this paper, we provide econometric evidence linking the raising of STCs on TBTs and the request for consultation citing the TBT agreement. In other words, TBT STCs on a given product increases the probability of raising a request for consultation citing the TBT agreement within the DSM on that traded product.

Thus, we believe that trade economists should analyze both sources, i.e., STCs and disputes, in order to find out whether TBT measures are creating unnecessary barriers to trade. Moreover, an increase in the number of TBT STCs can be interpreted as a warning signal for new, costly, and longlasting disputes within the WTO system. This signalling effect usually disappears after one year. This probably means that majority of exporters can adjust the characteristics of their products to the new regulations. Thus, TBTs can in the long run - as it has been demonstrated in some empirical studies - increase the transparency of the market and stimulate international trade. 


\section{References}

Aisbett, E., \& Pearson, L. M. (2012). Environmental and Health Protections, or New Protectionism? Determinants of SPS Notifications by WTO Members. Determinants of SPS Notifications by WTO Members (December 21, 2012). Crawford School Research Paper, (12-13).

Busch, M. L., \& Reinhardt, E. (2003). Developing Countries and General Agreement on Tariffs and Trade/World Trade Organization Dispute Settlement. Journal of World Trade, 37(4).

Feinberg, R. M., \& Reynolds, K. M. (2007). Tariff Liberalisation and Increased Administrative Protection: Is There a Quid Pro Quo?. World Economy, 30(6). DOI: $10.1111 / \mathrm{j} .1467-9701.2007 .01016 . x$.

Geraats, P. M. (2002). Central Bank Transparency. Economic Journal, 112(483). DOI: $10.1111 / 1468-0297.00082$.

Ghodsi, M. (2015). Determinants of Specific Trade Concerns Raised on Technical Barriers to Trade. Verein "Wiener Inst. für Internat. Wirtschaftsvergleiche"(WIIW), 117.

Kono, D. Y. (2006). Optimal Obfuscation: Democracy and Trade Policy Transparency. American Political Science Review, 100(03).

Moore, M. O., \& Zanardi, M. (2011). Trade Liberalization and Antidumping: Is There a Substitution Effect?. Review of Development Economics, 15(4). DOI: 10.1111/j.1467-9361.2011.00630.x.

Newey, W. K., \& West, K. D. (1994). Automatic Lag Selection in Covariance Matrix Estimation. Review of Economic Studies, 61(4).

Otsuki, T., Maskus, K. E., \& Wilson, J. S. (1999). Quantifying the Impact of Technical Barriers to Trade: A Framework for Analysis. World Bank Policy Research Working Paper, (2512).

Otsuki, T., Wilson, J. S., \& Sewadeh, M. (2001). Saving Two in a Billion: Quantifying the Trade Effect of European Food Safety Standards on African Exports. Food policy, 26(5).

Ray, E. J. (1981). The Determinants of Tariff and Nontariff Trade Restrictions in the United States. Journal of Political Economy, 89.

Rules, D. S. (1994). Understanding on Rules and Procedures Governing the Settlement of Disputes. Marrakesh Agreement Establishing the World Trade Organization, Annex, 2, 1869.

Santana, R., \& Jackson, L. A. (2012). Identifying Non-tariff Barriers: Evolution of Multilateral Instruments and Evidence from the Disputes (1948-2011). World Trade Review, 11(03).

Swann, P. (2010). The Economics of Standardization: an Update. Report for the UK Department of Business, Innovation and Skills (BIS).

Swinnen, J., \& Vandemoortele, T. (2012). Trade and the Political Economy of Standards. World Trade Review, 11(03).

UNCTAD (2013). Non-tariff Measure to Trade: Economic and Policy Issues for Developing Countries. UNCTAD/DITC/TAB/2012/2. New York and Geneva: United Nations Publications. 
UNCTAD/WTO (2012). A Practical Guide to Trade Policy Analysis. Retrieved form http://vi.unctad.org/tpa/.

WTO (2012). World Trade Report 2012. Trade and Public Policies: A Closer Look at Non-tariff Measures in the 21st Century. Geneva: WTO Publications.

Yu, Z. (2000). A Model of Substitution of Non-tariff Barriers for Tariffs. Canadian Journal of Economics/Revue canadienne d'économique, 33(4).

\section{Appendix}

Table 8. Countries (groups of countries) respondents of STCs raised by other members

\begin{tabular}{|c|c|c|c|c|c|c|c|}
\hline & $\begin{array}{l}\text { Member } \\
\text { Maintaining }\end{array}$ & No. Obs. & No. STCs & No & $\begin{array}{l}\text { Member } \\
\text { Maintaining }\end{array}$ & No. Obs. & $\begin{array}{l}\text { No. } \\
\text { STCs }\end{array}$ \\
\hline 1 & European Union & 3138 & 64 & 23 & Chile & 174 & 2 \\
\hline 2 & China & 1366 & 39 & 24 & Viet Nam & 68 & 2 \\
\hline 3 & United States & 1083 & 35 & 25 & Hong Kong, China & 13 & 2 \\
\hline 4 & Korea, Republic of & 698 & 25 & 26 & Moldova & 8 & 2 \\
\hline 5 & India & 642 & 18 & 27 & Norway & 2 & 2 \\
\hline 6 & Brazil & 635 & 18 & 28 & $\begin{array}{l}\text { Saudi Arabia, Bahrain, } \\
\text { Kuwait }\end{array}$ & 465 & 1 \\
\hline 7 & Japan & 198 & 11 & 29 & Kuwait & 247 & 1 \\
\hline 8 & Indonesia & 613 & 10 & 30 & Tunisia & 161 & 1 \\
\hline 9 & Mexico & 509 & 9 & 31 & Ukraine & 161 & 1 \\
\hline 10 & Canada & 177 & 9 & 32 & Venezuela & 44 & 1 \\
\hline 11 & Colombia & 78 & 8 & 33 & Qatar & 20 & 1 \\
\hline 12 & Argentina & 177 & 7 & 34 & Kenya & 17 & 1 \\
\hline 13 & Thailand & 29 & 6 & 35 & Croatia & 11 & 1 \\
\hline 14 & Taipei, Chinese & 399 & 5 & 36 & Philippines & 10 & 1 \\
\hline 15 & South Africa & 341 & 4 & 37 & Switzerland & 6 & 1 \\
\hline 16 & Egypt & 249 & 4 & 38 & Australia & 2 & 1 \\
\hline 17 & Turkey & 23 & 4 & 39 & Uruguay & 2 & 1 \\
\hline 18 & Israel & 12 & 4 & 40 & Bahrain & 1 & 1 \\
\hline 19 & Malaysia & 65 & 3 & 41 & Jordan & 1 & 1 \\
\hline 20 & Peru & 62 & 3 & 42 & Saudi Arabia & 1 & 1 \\
\hline 21 & Ecuador & 11 & 3 & 43 & United Arab Emirates & 1 & 1 \\
\hline 22 & New Zealand & 506 & 2 & & & & \\
\hline
\end{tabular}

Source: own calculations from STC database. 
Table 9. Products at 2-digit HS 2 level in the focus of STCs

\begin{tabular}{|c|c|c|c|c|c|c|c|c|c|c|c|}
\hline Rank & Codes & N. STC & N. Obs. & Rank & Codes & N. STC & N. Obs. & Rank & Codes & N. STC & N. Obs. \\
\hline 1 & 22 & 57 & 543 & 28 & 29 & 12 & 511 & 55 & 50 & 6 & 42 \\
\hline 2 & 85 & 41 & 428 & 29 & 61 & 12 & 329 & 56 & 24 & 6 & 15 \\
\hline 3 & 2 & 40 & 480 & 30 & 95 & 12 & 68 & 57 & 34 & 5 & 72 \\
\hline 4 & 84 & 40 & 291 & 31 & 62 & 11 & 337 & 58 & 39 & 5 & 11 \\
\hline 5 & 4 & 38 & 388 & 32 & 63 & 11 & 164 & 59 & 25 & 5 & 10 \\
\hline 6 & 3 & 36 & 290 & 33 & 72 & 11 & 97 & 60 & 37 & 4 & 71 \\
\hline 7 & 21 & 34 & 224 & 34 & 30 & 11 & 93 & 61 & 70 & 4 & 30 \\
\hline 8 & 19 & 34 & 191 & 35 & 64 & 10 & 111 & 62 & 68 & 4 & 20 \\
\hline 9 & 16 & 34 & 188 & 36 & 69 & 10 & 47 & 63 & 96 & 4 & 5 \\
\hline 10 & 15 & 33 & 770 & 37 & 55 & 8 & 189 & 64 & 41 & 3 & 40 \\
\hline 11 & 8 & 32 & 523 & 38 & 58 & 8 & 91 & 65 & 71 & 3 & 23 \\
\hline 12 & 12 & 32 & 511 & 39 & 60 & 8 & 83 & 66 & 74 & 3 & 13 \\
\hline 13 & 7 & 31 & 519 & 40 & 65 & 8 & 45 & 67 & 48 & 3 & 11 \\
\hline 14 & 9 & 31 & 363 & 41 & 43 & 8 & 35 & 68 & 86 & 3 & 10 \\
\hline 15 & 20 & 31 & 326 & 42 & 32 & 7 & 167 & 69 & 6 & 3 & 8 \\
\hline 16 & 11 & 30 & 326 & 43 & 51 & 7 & 88 & 70 & 83 & 3 & 4 \\
\hline 17 & 10 & 30 & 291 & 44 & 54 & 7 & 78 & 71 & 91 & 2 & 22 \\
\hline 18 & 18 & 30 & 217 & 45 & 56 & 7 & 74 & 72 & 44 & 2 & 18 \\
\hline 19 & 33 & 29 & 279 & 46 & 52 & 7 & 73 & 73 & 75 & 2 & 16 \\
\hline 20 & 17 & 29 & 144 & 47 & 53 & 7 & 73 & 74 & 5 & 2 & 12 \\
\hline 21 & 87 & 26 & 223 & 48 & 31 & 7 & 67 & 75 & 82 & 2 & 11 \\
\hline 22 & 90 & 26 & 119 & 49 & 36 & 7 & 65 & 76 & 27 & 2 & 5 \\
\hline 23 & 94 & 18 & 32 & 50 & 42 & 7 & 42 & 77 & 76 & 2 & 2 \\
\hline 24 & 1 & 14 & 114 & 51 & 73 & 7 & 36 & 78 & 92 & 1 & 3 \\
\hline 25 & 40 & 14 & 100 & 52 & 57 & 7 & 35 & 79 & 26 & 1 & 2 \\
\hline 26 & 38 & 13 & 295 & 53 & 35 & 6 & 73 & 80 & 88 & 1 & 2 \\
\hline \multirow[t]{2}{*}{27} & 28 & 12 & 578 & 54 & 59 & 6 & 66 & 81 & 23 & 1 & 1 \\
\hline & & & & & & & & 82 & Undefined & 42 & 57 \\
\hline
\end{tabular}

The last one (rank 82) is for all those STCs that do not have defined product in the database.

Source: own calculations from STC database. 